\title{
Diversity and metabolic impact of intestinal Lactobacillus species in healthy adults and the elderly
}

\author{
Jelena Štšepetova ${ }^{1 *}$, Epp Sepp ${ }^{1}$, Helgi Kolk $^{2}$, Krista Lõivukene ${ }^{3}$, Epp Songisepp $^{4}$ and Marika Mikelsaar $^{1}$ \\ ${ }^{1}$ Department of Microbiology, Medical Faculty, University of Tartu, Tartu 50411, Estonia \\ ${ }^{2}$ Department of Traumatology and Orthopedics, University of Tartu, Tartu, Estonia \\ ${ }^{3}$ Laboratory of Microbiology, Tartu University Hospital, Tartu, Estonia \\ ${ }^{4}$ Bio-competence Center of Healthy Dairy Production Limited, Tartu, Estonia \\ (Received 7 June 2010 - Revised 15 October 2010 - Accepted 19 October 2010 - First published online 8 February 2011)
}

\section{Abstract}

The present study aimed at assessing the counts and species distribution of intestinal lactobacilli and exploring if the data are associated with BMI and blood glucose level in healthy adults and elderly persons. The BMI $(P<0 \cdot 01)$, the level of fasting blood glucose $(P<0 \cdot 001)$ and the total counts of lactobacilli $(P<0.01$ by bacteriology; $P<0.001$ by real-time PCR) were higher in the elderly. The number of species in adults was lower $(P<0 \cdot 05)$, who were more often colonised with Lactobacillus acidophilus $(P=0 \cdot 031)$ and $L$. helveticus $(P<0 \cdot 001)$. In contrast, $L$. plantarum $(P=0.035)$, . paracasei $(P<0.001)$ and $L$. reuteri $(P=0.031)$ were more prevalent in the elderly. $L$. rhamnosus was detected in adults $(P<0 \cdot 001)$, but not in any elderly person. BMI was associated with counts of lactobacilli, adjusted for age and sex $(P=0.008)$. The higher BMI in both groups of persons was associated with the presence of obligate homofermentative lactobacilli and L. sakei, both adjusted for age and sex. Plasma glucose values were positively correlated with BMI and negatively correlated with colonisation with $L$. paracasei $(P=0.0238)$ in adults and on the borderline with $L$. fermentum $(P=0.052)$ in the elderly. Thus, the species-specific PCR analysis of Lactobacillus sp. combined with viable plating data indicates substantial age-related structural differences in the intestinal lactobacilli communities. The higher counts of intestinal Lactobacillus sp. are associated with higher BMI and blood glucose content, while their specific fermentative groups and species of lactobacilli appear at different glucose levels both in adults and in the elderly.

Key words: Metabolic impact: Lactobacillus species: Faecal microbiota: Adults: Elderly

A host and its microbiota form a tightly linked microbial ecosystem. This has several health consequences that expose differentially during the lifespan. The changes in the bacterial colonisation of the gut and metabolic activities in the colonic ecosystem occur during ageing ${ }^{(1,2)}$. In the elderly, the country-specific increased prevalence and the number of Lactobacillus species during ageing have been assessed $^{(2-4)}$.

Lactobacillus sp. belongs to the members of lactic acid bacteria $^{(5-7)}$ and is phylogenetically included in the division of Firmicutes $^{(8)}$. The genus Lactobacillus comprises more than ninety validly described species and some subspecies, while approximately $30 \%$ of them have been isolated from faecal sources ${ }^{(9)}$ (www.bacterio.cict.fr). The role of lactobacilli has received much attention, especially due to their putative health-promoting properties. Lactobacillus sp. has been shown to contribute to digestion, stimulation of immunity and inhibition of pathogens ${ }^{(7,10-13)}$. Recently, some studies have reported an association between the presence of intestinal lactobacilli and an impact on metabolism and energy uptake in the host ${ }^{(14)}$.

However, there are a few comparative studies of Lactobacillus species diversity among different ages in adults and elderly groups, either by applying bacteriological methods ${ }^{(15,16)}$ or by using denaturing gradient gel electrophoresis with Lactobacillus genus-specific primers $^{(17-19)}$. The classical division of lactobacilli has been based on their fermentative characteristics: obligate homofermentative lactobacilli (OHOL); facultative heterofermentative lactobacilli (FHEL); obligate heterofermentative lactobacilli (OHEL) ${ }^{(20)}$. During fermentation of polysaccharides in the colon, the lactobacilli strains of particular species may use different pathways, providing the host with energy differentially. Recent work by the Gordon team has shown that Gram-positive

Abbreviations: CFU, colony-forming unit; FHEL, facultative heterofermentative lactobacilli; OHEL, obligate heterofermentative lactobacilli; OHOL, obligate homofermentative lactobacilli; RT-PCR, real-time PCR.

* Corresponding author: J. Štšepetova, fax +3727374 172, email jelena.stsepetova@ut.ee 
bacteria of the Firmicutes phylum rather than those of Bacteroidetes expressed specific enzymatic activities in obese individuals ${ }^{(21)}$. Whether this process is influenced by differences in age, sex and increased body weight has not been elucidated yet.

The aim of the present study was to assess the counts and species distribution of intestinal lactobacilli and to explore if the data of intestinal lactobacilli are associated with BMI and blood glucose level in healthy adults and elderly persons.

\section{Materials and methods}

\section{Sampling and processing of samples}

The study group comprised twenty-four healthy adults (nine males and fifteen females; age: median 27.0 years (quartiles 23-31.5)) and thirty-seven elderly persons (sixteen males and twenty-one females; age: median 73 years (quartiles 68-75.2)), $P<0.001$ (Table 1). The present study was conducted according to the guidelines laid down in the Declaration of Helsinki. The study was approved by the Ethics Committee of the Medical Faculty of the University of Tartu (no. 139/16 20.06.2005). The baseline values of healthy adults have been included from the study assessing the impact of a probiotic product (ISRCTN38739209, also approved by the aforementioned Ethics Committee (approval no. 158/10 26.03.2007)). The inclusion criteria for adults were as follows: considering themselves healthy, no gastrointestinal disorders and no recent history of antibiotic treatment.

The healthy elderly were selected from the registry of family doctors and orthopaedists of the Tartu University Hospital, Estonia, before performing elective orthopaedic surgery. The inclusion criteria for volunteers were as follows: age 65 years or above, considering themselves generally healthy and had not had any recent antibiotic treatment.

Both adults and the elderly wished to participate in the study, which was confirmed by written informed consent. Subjects following special dietary routines, having an unstable cardiopulmonary system, with a history of diabetes and malignancy, chronic renal or hepatic failure, gut surgery, the presence of an acute illness 4 weeks before the study, on anti-hypertensive medication, with recent use of corticosteroids, non-steroid anti-inflammatory drugs, antibiotics during the last 2 months or with a history of alcohol abuse were excluded from participation in the present study.

Subjects in both groups consumed habitually a Westerntype diet, typically rich in potatoes, vegetables, meat, eggs but characterised also with a high content of fibre (rye bread, oat/wheat/rice porridge) and dairy products, vegetable seed oils, margarine and non-alcoholic beverages $^{(22,23)}$.

Participants' body weight was measured in light clothing to the nearest $0 \cdot 1 \mathrm{~kg}$ using a calibrated scale. Height was measured without shoes to the nearest $0 \cdot 1 \mathrm{~cm}$ using a vertical ruler. BMI was calculated as weight $(\mathrm{kg})$ divided by height squared $\left(\mathrm{m}^{2}\right)^{(24)}$.

Blood samples were obtained in the early morning after $8 \mathrm{~h}$ of fasting. Samples were drawn from the antecubital vein with a vacutainer into heparinised tubes and immediately stored (on ice) at $4^{\circ} \mathrm{C}$. Plasma glucose (mmol/l) was determined by standard laboratory methods using certified assays in the local clinical laboratory of the Tartu University Hospital. The reference values for human BMI $\left(\mathrm{kg} / \mathrm{m}^{2}\right)$ and glucose in blood $(\mathrm{mmol} / \mathrm{l})$ are presented in Table 1 .

Approximately $2 \mathrm{~g}$ of fresh stool samples were placed into sterile containers. The samples collected at home or at the hospital were kept in a domestic refrigerator at $4^{\circ} \mathrm{C}$ for not more than $2 \mathrm{~h}$ before transportation to the laboratory, where the containers were stored frozen at $-70^{\circ} \mathrm{C}$ until use.

\section{Counts of lactobacilli in faeces by the bacteriological method}

For bacteriological analyses, the weighed samples of faeces were serially diluted $\left(10^{-2}-10^{-9}\right)$ in pre-reduced phosphate buffer ( $\mathrm{pH} 7 \cdot 2$ ) inside an anaerobic glove box (Sheldon Manufacturing, Inc., Cornelius, OR, USA), with a gas mixture $\left(5 \% \mathrm{CO}_{2}, 5 \% \mathrm{H}_{2}\right.$ and $\left.90 \% \mathrm{~N}_{2}\right)$. A quantitative analysis of the gut bacteria was performed using duplicate samples of $0.05 \mathrm{ml}$ of each dilution on the de ManRogosa-Sharpe agar (Oxoid, Basingstoke Hampshire, UK) for micro-aerobic lactobacilli. The de Man-RogosaSharpe agar was incubated in a micro-aerobic atmosphere

Table 1. Clinical data of adults and the elderly persons ( $>65$ years)

(Mean values and standard deviations)

\begin{tabular}{|c|c|c|c|c|c|c|}
\hline \multirow[b]{2}{*}{ Indices } & \multicolumn{2}{|c|}{ Adults ( $n$ 24) } & \multicolumn{2}{|c|}{ Elderly ( $n$ 37) } & \multirow[b]{2}{*}{$P$} & \multirow[b]{2}{*}{ Reference values ${ }^{(24)}$} \\
\hline & $\overline{\text { Mean }}$ & SD & $\overline{\text { Mean }}$ & SD & & \\
\hline Age (years) & $29 \cdot 2$ & $8 \cdot 2$ & 72.5 & $5 \cdot 0$ & $<0.001$ & $>65$ Years old (elderly) \\
\hline BMI $\left(\mathrm{kg} / \mathrm{m}^{2}\right)$ & 24.5 & $4 \cdot 1$ & $27 \cdot 2$ & $4 \cdot 2$ & 0.012 & $\begin{array}{l}\text { Normal: } 18 \cdot 5-24.9 \\
\text { Overweight: }>25 \\
\text { Obese: }>30\end{array}$ \\
\hline $\begin{array}{l}\text { Fasting plasma } \\
\text { glucose }(\mathrm{mmol} / \mathrm{l})\end{array}$ & 4.5 & 0.50 & $5 \cdot 2$ & 0.60 & $<0.001$ & $3 \cdot 1-6 \cdot 4$ \\
\hline
\end{tabular}


( $\mathrm{CO}_{2}$-incubator 'Jouan' IG 150, Saint-Herblain, France), with a gas mixture $\left(10 \% \mathrm{CO}_{2}\right)$ at $37^{\circ} \mathrm{C}$ for $48 \mathrm{~h}^{(25)}$. The colony counts of the different faecal dilutions on de Man-Rogosa-Sharpe media were recorded. All colonies of different morphology grown from the highest dilutions on de Man-Rogosa-Sharpe agar were isolated, and the lactobacilli were identified according to Gram-positive rodshaped morphology and the negative catalase test ${ }^{(20,26)}$.

The lactobacilli composition of the gut microbiota was expressed as counts ( $\log _{10}$ colony-forming units (CFU)/g) and prevalence (\%) of lactobacilli. The detection level of the micro-organisms was $\geq 3 \log \mathrm{CFU} / \mathrm{g}$.

\section{Molecular identification of Lactobacillus sp.}

DNA extraction. Bacterial DNA from the faecal samples was extracted using a QIAamp DNA stool mini kit (Qiagen, Hilden, Germany) with some modifications. In $200 \mu \mathrm{l}$ of $10 \mathrm{~mm}$-Tris, $10 \mathrm{~mm}$-EDTA buffer (pH 8; lysozyme $(20 \mathrm{mg} / \mathrm{ml})$ and mutanolysin (200 units/ml)), $0 \cdot 22 \mathrm{~g}$ of faeces were resuspended and incubated for $1 \mathrm{~h}$ at $37^{\circ} \mathrm{C}$. Then, $0.3 \mathrm{~g}$ of $0.1 \mathrm{~mm}$ zirconia/silica beads and $1.4 \mathrm{ml}$ of ASL solution (Qiagen) from the stool mini kit were added to the faecal samples. The tubes were then agitated for $3 \mathrm{~min}$ at a speed of $5000 \mathrm{rpm}$ in a mini-bead beater (Biospec Products, Inc., Bartlesville, OK, USA). The protocol was then continued as described by the manufacturer (Qiagen).

Quantitative analysis of total lactobacilli by real-time$P C R$. In order to establish a quantitative assay, we cloned plasmids containing the amplified region of target bacteria using the pGEM-T vector system (Promega, Madison, WI, USA). The PCR amplicon for L. paracasei was individually inserted into a separate plasmid vector; the recombinant vector was transformed in chemically competent Escherichia coli. Plasmids were purified with MaxiPrep (Qiagen). The purified plasmids were quantified by spectrophotometry (Quibit ${ }^{\mathrm{TM}}$; Invitrogen, Carlsbad, CA, USA) of multiple dilutions ${ }^{(27)}$. Quantification of target DNA was achieved by using serial tenfold dilutions from $10^{2}$ to $10^{9}$ plasmid copies of the previously quantified plasmid standards. Plasmid standards and samples were run in triplicate, and the average values were used for the calculation of the bacterial load.

Real-time PCR (RT-PCR) was performed with the ABI PRISM 7500 HT Sequence Detection System (Applied Biosystems, Bedford, MA, USA) using optical-grade ninety-six-well plates. The PCR was performed on a total volume of $25 \mu \mathrm{l}$ using SYBR Green PCR Master mix (Applied Biosystems). Each reaction included $150 \mathrm{ng}$ of template DNA, $12.5 \mu \mathrm{l}$ of SYBR Green PCR Master mix (Applied Biosystems) and $2 \mu \mathrm{M}$ of each primer ${ }^{(5,28)}$ (Table 2). The conditions were set as follows: $2 \mathrm{~min}$ at $50^{\circ} \mathrm{C}$ and $10 \mathrm{~min}$ at $95^{\circ} \mathrm{C}$, followed by forty cycles consisting of denaturation at $95^{\circ} \mathrm{C}$ for $15 \mathrm{~s}$, and annealing and elongation at $60^{\circ} \mathrm{C}$ for $1 \mathrm{~min}$. Data analysis was conducted with Sequence Detection Software version 1.6.3, supplied by Applied Biosystems.

Reference strains. The reference strains used in the study were composed of three different fermentation groups ${ }^{(29)}$ of Lactobacillus: OHOL L. acidophilus ATCC 4356, L. delbrueckii spp. delbrueckii ATCC 9649, L. salivarius DSM 20555, L. crispatus DSM 20584, L. johnsonii DSM 10533, L. gasseri DSM 20077, L. helveticus DSM 20075; FHEL L. paracasei DSM 20020, L. ruminis DSM 20403, L. curvatus ATCC 2560, L. casei NCDC 150, L. rhamnosus ATCC 53103, L. plantarum DSM 9843, L. sakei DSM 20100; OHEL L. fermentum ATCC 14931, L. reuteri DSM 20016, L. brevis DSM 20054, L. buchneri DSM 5987.

Species-specific PCR analysis of Lactobacillus sp. in faecal samples. The Lactobacillus species-specific qualitative PCR was carried out by primers listed in Table 2, targeted on the 16S-23S ribosomal RNA intergenic spacer region ${ }^{(18,30-32)}$. The primer pair for the L. ruminis subgroup is specific for L. ruminis, L. animalis, L. mali, L. salivarius and L. satsumensis ${ }^{(33)}$. A reaction mixture $(50 \mu \mathrm{l})$ consisted of $10 \times$ reaction buffer, a $200 \mu \mathrm{M}$ concentration of each deoxynucleoside triphosphate, $1 \mu \mathrm{m}$ of each primer, $100 \mathrm{ng}$ of bacterial DNA (extracted from the faecal samples) and $1.5 \mathrm{U}$ of HotStar Taq Plus DNA polymerase (Qiagen). The amplification programme consisted of predenaturation at $94^{\circ} \mathrm{C}$ for $5 \mathrm{~min}$, followed by thirty-five cycles of $94^{\circ} \mathrm{C}$ for $30 \mathrm{~s}, 30 \mathrm{~s}$ at the appropriate annealing temperature (Table 2), and finally $72^{\circ} \mathrm{C}$ for $30 \mathrm{~s}$. A cycle of $72^{\circ} \mathrm{C}$ for $10 \mathrm{~min}$ concluded the programme. Amplification products were detected by agarose gel electrophoresis on $2 \%$ agarose gel, ethidium bromide staining and UV transillumination.

The size of the PCR products was compared with that of the aforementioned Lactobacillus reference strains.

\section{Statistical analyses}

The statistical analysis was performed using the SIGMASTAT 2.0 (Jandel Scientific Corporation, San Rafael, CA, USA) and the SPSS 11.0 (SPSS, Inc., Chicago, IL, USA) statistical software packages. Data are presented as means and standard deviations or ranges and medians. Bacterial count data were logarithmically transformed; the prevalence of the species was expressed as a percentage.

According to the data of the descriptive statistics, Student's $t$ test and the Mann-Whitney rank-sum test were applied to compare the differences in clinical and microbiological indices. Logistic regression analyses were performed to compare the binary variables and/or continuous variables. The Spearman rank correlation test and the multiple linear regression models were used to test the associations between microbiological and clinical or biochemical indices in both groups. The models were adjusted for BMI, age and sex. All differences were considered statistically significant if $P<0.05$. 
Table 2. List of primers used for the detection of Lactobacillus spp. ${ }^{(18,30-32)}$

\begin{tabular}{|c|c|c|c|c|c|}
\hline Group & Target & Primers & Sequence $\left(5^{\prime}-3^{\prime}\right)$ & $\begin{array}{c}\text { Annealing } \\
\text { temperature }\left({ }^{\circ} \mathrm{C}\right)\end{array}$ & $\begin{array}{l}\text { Amplicon } \\
\text { length (bp) }\end{array}$ \\
\hline \multirow[t]{8}{*}{$\mathrm{OHOL}$} & L. acidophilus & $\begin{array}{l}\text { F_acid_IS } \\
\text { R_acid_IS }\end{array}$ & $\begin{array}{l}\text { GAAAGAGCCCAAACCAAGTGATT } \\
\text { CTTCCCAGATAATTCAACTATCGCTTA }\end{array}$ & 59 & 85 \\
\hline & L. helveticus & $\begin{array}{l}\text { F_helv_IS } \\
\text { R_helv_IS }\end{array}$ & $\begin{array}{l}\text { CTCTTCTCGGTCGCCTTG } \\
\text { GAAGTGATGGAGAGTAGAGATTA }\end{array}$ & 56 & 160 \\
\hline & L. delbrueckii & $\begin{array}{l}\text { R_delb_IS } \\
\text { F_delb_IS }\end{array}$ & $\begin{array}{l}\text { CGAACTCTCTCGGTCTT } \\
\text { CACTTGTACGTTGAAAACTGAATATCTTAA }\end{array}$ & 58 & 94 \\
\hline & L. salivarius & $\begin{array}{l}\text { R_sal_IS } \\
\text { F_sal_IS }\end{array}$ & $\begin{array}{l}\text { GTCGTAACAAGGTAGCCGTAGGA } \\
\text { TAAACAAAGTATTCGATAAATGTACAGGTT }\end{array}$ & 61 & 97 \\
\hline & L. crispatus & $\begin{array}{l}\text { R_cri_IS } \\
\text { F_cri_IS }\end{array}$ & $\begin{array}{l}\text { GTAATGACGTTAGGAAAGGG } \\
\text { ACTACCAGGGTATCTAATGG }\end{array}$ & 57 & 85 \\
\hline & L. johnsonii & $\begin{array}{l}\text { R_joh_IS } \\
\text { F_joh_IS }\end{array}$ & $\begin{array}{l}\text { GAGCTTGCCTAGTAGATTTTA } \\
\text { ACTACCAGGGTATCTAATCC }\end{array}$ & 58 & 80 \\
\hline & L. gasseri & $\begin{array}{l}\text { R_gas_IS } \\
\text { F_gas_IS }\end{array}$ & $\begin{array}{l}\text { AGCGACCGAGAAGAGAGAGA } \\
\text { TGCTATCGCTTCAAGTGCTT }\end{array}$ & 57 & 360 \\
\hline & L. ruminis subgroup & $\begin{array}{l}\text { F_rum_sub } \\
\text { R_rum_sub }\end{array}$ & $\begin{array}{r}\text { CACCGAATGCTTGCAYTCACC } \\
\text { GCCGCGGGTCCATCCAAAA }\end{array}$ & 57 & 182 \\
\hline \multirow[t]{4}{*}{ OHEL } & L. fermentum & $\begin{array}{l}\text { R_ferm_IS } \\
\text { F_ferm_IS }\end{array}$ & $\begin{array}{l}\text { ACTTAACCTTACTGATCGTAGATCAGTCA } \\
\text { AACCGAGAACACCGCGTTAT }\end{array}$ & 58 & 88 \\
\hline & L. reuteri & $\begin{array}{l}\text { F_reut_IS } \\
\text { R_reut_IS }\end{array}$ & $\begin{array}{l}\text { ACCGAGAACACCGCGTTATTT } \\
\text { CATAACTTAACCTAAACAATCAAAGATTGTCT }\end{array}$ & 59 & 93 \\
\hline & L. brevis & $\begin{array}{l}\text { F_bre_IS } \\
\text { R_bre_IS }\end{array}$ & $\begin{array}{l}\text { ATTTTTGTTTGAAAGGTGGCTTCGG } \\
\text { ACCCTTGAACAGTTACTCTCAAAGG }\end{array}$ & 55 & 289 \\
\hline & L. buchneri & $\begin{array}{l}\text { R_buc_IS } \\
\text { F_buc_IS }\end{array}$ & $\begin{array}{l}\text { GGACCAATGGAGCAACTGAA } \\
\text { AGATTACTGACGCATTGGTTACCA }\end{array}$ & 55 & 72 \\
\hline \multirow[t]{7}{*}{ FHEL } & L. casei & $\begin{array}{l}\text { R_casei_IS } \\
\text { F_casei_IS }\end{array}$ & $\begin{array}{l}\text { CTTCCTGCGGGTACTGAGATGT } \\
\text { CTATAAGTAAGCTTTGATCCGGAGATTT }\end{array}$ & 59 & 132 \\
\hline & L. paracasei & $\begin{array}{l}\text { F_paca_IS } \\
\text { R_paca_IS }\end{array}$ & $\begin{array}{l}\text { ACATCAGTGTATTGCTTGTCAGTGAATAC } \\
\text { CCTGCGGGTACTGAGATGTTTC }\end{array}$ & 60 & 80 \\
\hline & L. plantarum & $\begin{array}{l}\text { F_plan_IS } \\
\text { R_plan_IS }\end{array}$ & $\begin{array}{l}\text { TGGATCACCTCCTTTCTAAGGAAT } \\
\text { TGTTCTCGGTTTCATTATGAAAAAATA }\end{array}$ & 60 & 144 \\
\hline & L. rhamnosus & $\begin{array}{l}\text { F_rham_IS } \\
\text { R_rham_IS }\end{array}$ & $\begin{array}{l}\text { CGGCTGGATCACCTCCTTT } \\
\text { GCTTGAGGGTAATCCCCTCAA }\end{array}$ & 59 & 97 \\
\hline & L. curvatus & $\begin{array}{l}\text { R_cur_IS } \\
\text { F_cur_IS }\end{array}$ & $\begin{array}{l}\text { TTGGTACTATTTAATTCTTAG } \\
\text { GCTGGATCACCTCCTTTC }\end{array}$ & 58 & 305 \\
\hline & L. sakei & $\begin{array}{l}\text { R_sak_IS } \\
\text { F_sak_IS }\end{array}$ & $\begin{array}{l}\text { GAGCTAATCCCCCATAATGAAACTAT } \\
\text { GATAAGCGTGAGGTCGATGGTT }\end{array}$ & 57 & 78 \\
\hline & Lactobacillus group & $\begin{array}{l}\text { Lac-F } \\
\text { Lac-R }\end{array}$ & $\begin{array}{c}\text { AGCAGTAGGGAATCTTCCA } \\
\text { CACCGCTACACATGGAG }\end{array}$ & 58 & 341 \\
\hline
\end{tabular}

OHOL, obligate homofermentative lactobacilli; OHEL, obligate heterofermentative lactobacilli; FHEL, facultative heterofermentative lactobacilli.

\section{Results}

\section{Clinical indices}

Clinical indices of both groups are presented in Table 1. BMI was significantly higher in the elderly $(P=0 \cdot 012)$. Similarly, the level of fasting blood glucose was higher in the elderly $(P<0 \cdot 001)$.

\section{Quantification of lactobacilli in faeces by the culture} method and real-time PCR

The culture method and RT-PCR were used to determine the total number of lactobacilli in the faeces of healthy adults and the elderly.

Lactobacilli were cultured from twenty-three (96\%) out of the twenty-four adults and from thirty-six (97\%) out of the thirty-seven elderly persons. In both groups, the viable counts were below the detection limit. According to the RT-PCR results, lactobacilli were found in all faecal samples of adults and the elderly. Both methods showed that in the elderly, the total counts of lactobacilli were significantly higher (3.6-10.8, median 6.4; mean $6 \cdot 8$ (SD 2.2) $\log _{10} \mathrm{CFU} / \mathrm{g}$ of faeces $v$. 2.6-8.6, median 5.9; mean 5.3 (SD 1.8) $\log _{10} \mathrm{CFU} / \mathrm{g}$ of faeces; $P=0.008$ by the culture method and 7.0-9.5, median 7.9; mean 8.0 (SD 0.7) $\log _{10} \mathrm{CFU} / \mathrm{g}$ of faeces $v$. 5.3-8.8, median $7 \cdot 2$; mean 7.2 (SD 0.7$) \log _{10} \mathrm{CFU} / \mathrm{g}$ of faeces; $P=0.0002$ by RT-PCR) (Fig. 1)

The values obtained for lactobacilli by RT-PCR were higher than those obtained by the culture method (mean $7 \cdot 69$ (SD 0.80)/ $\log _{10} \mathrm{CFU} / \mathrm{g}$ of faeces $v$. mean $6 \cdot 19$ (SD 2.1)/ $\log _{10} \mathrm{CFU} / \mathrm{g}$ of faeces; $P=0 \cdot 007$ ).

Identification of lactobacilli by species-specific PCR and their relationship with a person's age

Species-specific PCR analysis was performed with all samples, even with samples that were negative in bacteriological analysis. According to the PCR method, the number of species in adults was lower than in the elderly: 4-12, median 8, adults $v$. 5-11, median 6, elderly $(P=0.042)$. There was no correlation detected between the number 

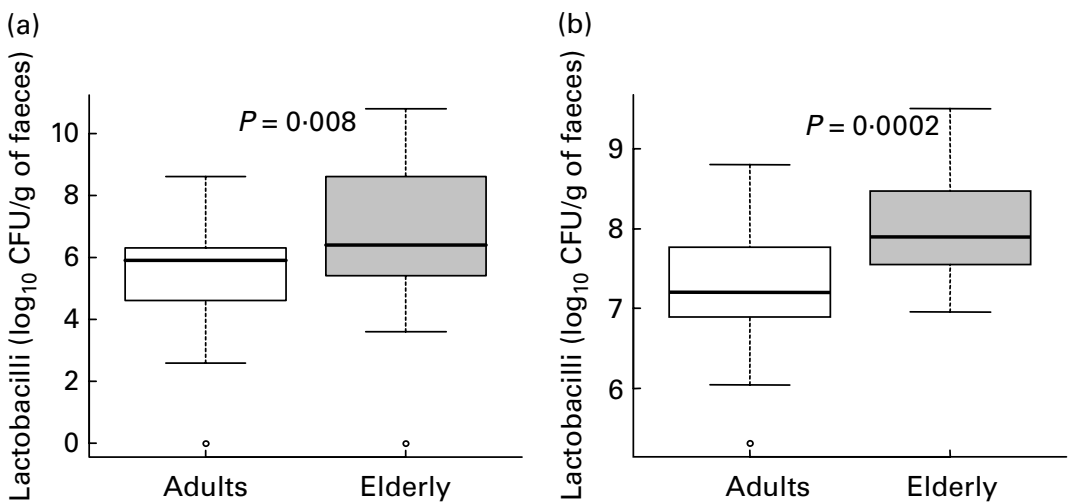

Fig. 1. Total counts of lactobacilli in adults and the elderly by (a) bacteriological analysis and (b) real-time-PCR. CFU, colony-forming units.

of species and the count of lactobacilli estimated, neither by the culture method nor by RT-PCR. The most prevalent Lactobacillus species detected both from adults and the elderly were $L$. case $i$ of the FHEL group and $L$. ruminis of the OHOL group ( $\geq 70 \%$; Fig. 2). The prevalence of $L$. crispatus was the lowest (8\%).

The age-related significant differences were found for six species of Lactobacillus. Concerning the OHOL metabolic pattern, the adults, in comparison with the elderly, were more often colonised with L. acidophilus (19/24, 79\% v. $18 / 37,47 \% ; P=0.031)$ and L. helveticus $(16 / 24,66 \% v$. $9 / 37,24 \% ; P=0.001)$. At the same time, L. johnsonii was detected only in the elderly $(5 / 37,13.5 \%$ ) (Fig. 2), and the age range of detection was older than 66 , median 68 years old.

In the FHEL group, L. plantarum $(22 / 37,59 \% v .7 / 24$, $29 \% ; P=0.035)$ and $L$. paracasei $(36 / 37,97 \% v .14 / 24$, $58 \% ; P=0.0002$ ) were more prevalent in the elderly than in adults. Surprisingly, L. rhamnosus was detected in seven $(29 \%)$ adults $(P<0.001)$, but not in any elderly person. The age range for the detection of L. rhamnosus was up to 48 , median 31 years old.
The species difference was found also in the OHEL group where the higher prevalence of L. reuteri (19/37, $51 \% v \cdot 5 / 24,21 \% ; P=0.031)$ and on the borderline also with L. buchneri $(11 / 37,29 \% v .2 / 24,8 \% ; P=0.059)$ was observed in elderly persons (Fig. 2).

\section{Comparison of lactobacilli counts and species with BMI, blood glucose and sex}

A positive correlation between BMI and age was found ( $r$ 0.301; $P=0.0185$ ), though sex was a confounding factor (Table 3). A positive correlation was found between BMI and fasting blood glucose content ( $r$ 0.463; $P<0 \cdot 0001)$, adjusted for age and sex. The lower blood glucose level was predicted by the presence of intestinal L. paracasei ( $r^{2}$ 0.281; adjusted $r^{2} 0.213 ; P=0.031$ ), adjusted for age in the adult group. A negative correlation of borderline significance was found between the level of blood glucose and colonisation by $L$. fermentum ( $r-0.321 ; P=0.052)$ in the elderly group. Multiple regression analysis revealed that BMI was associated with counts of cultivable lactobacilli adjusted for age

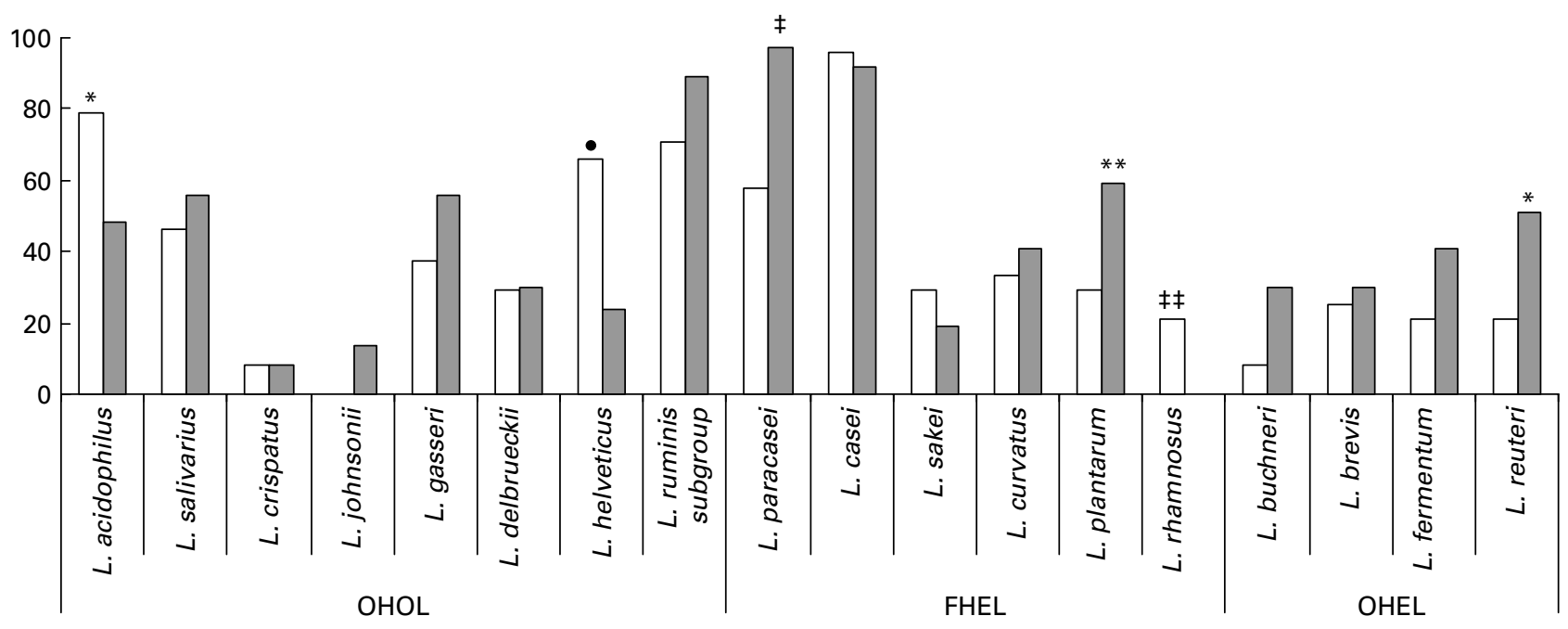

Fig. 2. Lactobacillus sp. diversity in adults $(\square)$ and the elderly $(\square)$. OHOL, obligate homofermentative lactobacilli; FHEL, facultative heterofermentative lactobacilli; OHEL, obligate heterofermentative lactobacilli. ${ }^{\star} P=0.031 ;{ }^{\bullet} P=0.001 ; \ddagger P=0.0002 ;{ }^{*} P=0.035 ;$; $¥ P=0.007$. 
Table 3. Spearman's rank-order correlation, linear and multiple linear regression analyses between counts and species of lactobacilli, BMI, age and sex

\begin{tabular}{|c|c|c|c|c|c|c|}
\hline \multirow[b]{2}{*}{ Variable 1} & \multicolumn{6}{|c|}{ Linear multiple regression analysis } \\
\hline & Variable 2 & Correlation coefficients $(r)$ & $P$ & $r^{2}$ & Adjusted $r^{2}$ & $P$ \\
\hline BMI $\left(\mathrm{kg} / \mathrm{m}^{2}\right)$ & Age (years) & 0.301 & 0.0185 & & & NS \\
\hline BMI $\left(\mathrm{kg} / \mathrm{m}^{2}\right)$ & Fasting plasma glucose $(\mathrm{mmol} / \mathrm{l})$ & 0.463 & 0.0001 & $0 \cdot 182^{*}$ & $0.139^{*}$ & $0.009^{*}$ \\
\hline Fasting plasma glucose $(\mathrm{mmol} / \mathrm{l})$ & Presence of Lactobacillus paracasei & -0.460 & 0.0238 & $0.281 \dagger$ & $0.213 \dagger$ & $0.031 \dagger$ \\
\hline Fasting plasma glucose $(\mathrm{mmol} / \mathrm{l})$ & Presence of Lactobacillus fermentum & -0.321 & 0.052 & & & NS \\
\hline BMI $\left(\mathrm{kg} / \mathrm{m}^{2}\right)$ & $\begin{array}{l}\text { Counts of lactobacilli (bacteriology; } \\
\log _{10} \text { CFU/g of faeces) }\end{array}$ & 0.309 & 0.00279 & $0 \cdot 187^{\star}$ & $0 \cdot 144^{*}$ & $0.008^{*}$ \\
\hline BMI $\left(\mathrm{kg} / \mathrm{m}^{2}\right)$ & Number of $\mathrm{OHOL}$ species & 0.598 & 0.00213 & & & NS \\
\hline BMI $\left(\mathrm{kg} / \mathrm{m}^{2}\right)$ & Presence of Lactobacillus sakei & 0.394 & 0.002 & $0.282^{*}$ & $0.244^{*}$ & $0.001^{*}$ \\
\hline
\end{tabular}

CFU, colony-forming units; OHOL, obligate homofermentative lactobacilli.

${ }^{*}$ Age, sex.

†Age (adult group).

and sex ( $r^{2}$ 0.187; adjusted $\left.r^{2} 0.144 ; P=0.008\right)$. The higher BMI in both groups of persons was directly predicted by the presence of OHOL and facultative heterofermentative L. sakei species, both adjusted for age and sex (Table 3).

\section{Discussion}

In the present study, the species-specific PCR analysis of Lactobacillus sp. combined with viable plating data indicates substantial age-related structural differences in the intestinal lactobacilli community of healthy adults and the elderly. In the elderly, the lactobacilli counts were higher, and their species composition was richer than those of younger persons. For the first time, it has been established that the values of BMI and glucose content are associated with counts, particular fermentation groups and species of intestinal Lactobacillus sp.

The present results confirm the previous culture-based studies, indicating higher viable counts of lactobacilli in healthy elderly people as compared with adults ${ }^{(2,34)}$. Lactobacilli generally account for less than $1 \%$ of the bacterial community of faeces; however, the composition of the lower parts of the gastrointestinal tract is still not well elaborated $^{(35)}$. In the present study, lactobacilli were detected in $90 \%$ of the faecal samples by the culture method and in all samples by RT-PCR. In the elderly, the higher counts of intestinal lactobacilli were assessed by both methodological approaches. At the same time, previous data based on viable counts have shown that lactobacilli were present in the gastrointestinal tract of only $70-73 \%$ of humans who consumed a Western-type $\operatorname{diet}^{(36,37)}$, while in a vegetarian diet, a higher prevalence of lactobacilli has been assessed ${ }^{(38)}$. In Estonia, the Western-type diet is characterised by the frequent use of fibre-rich rye bread, porridges and dairy products.

In the present study, we have had a unique possibility to compare both the cultivable and molecularly assessed counts and the PCR species composition of intestinal lactobacilli in adults and the elderly with the bacteriological data obtained previously in 1967-8 in Estonia, reviewed later ${ }^{(39)}$. The high prevalence and high counts of lactobacilli were characteristics of adults and the elderly both in the late 1960s and 35 years later. Astonishingly, also the decreased colonisation of the elderly by homofermentative L. acidophilus strains coincided in both periods, irrespective of the different identification methods: physiological/biochemical properties as compared with molecular assessment. At the same time, in infants and children, the colonisation by lactobacilli has significantly decreased during 5 years of industrial development and changes in lifestyle of the Estonian community ${ }^{(40)}$. It is probable that the microbiota that was formed at a young age did not change easily by growing old.

All eighteen lactobacilli species identified in the present study were previously described as members of the faecal microbiota of humans, though some were only recently detected by molecular techniques using specific PCR primers such as the $L$. gasseri and $L$. ruminis group $^{(13,41,42)}$. In the present study, L. acidophilus, L. salivarius, L. paracasei, L. casei, L. plantarum, L. brevis and $L$. fermentum were the most common species in both age groups, which is in agreement with previous studies $^{(7,43,44)}$. Reuter ${ }^{(42)}$ observed the predominance of $L$. reuteri among the indigenous intestinal lactobacilli, while some other authors reported this species as only a minor component of the OHEL group ${ }^{(17,28)}$ or completely absent in humans ${ }^{(7)}$. In our investigations, altogether $39 \%$ of the human subjects harboured $L$. reuteri.

Besides, the composition of intestinal lactobacilli varies widely between persons and location in the gastrointestinal tract. However, the present results showed that age groups differed in their species diversity, whereas L. jobnsonii. L. plantarum, L. paracasei, L. buchneri and L. reuteri were more prevalent in the elderly over 66 years of age. At the same time, L. acidophilus and L. helveticus of the OHOL group serve as more frequent colonisers of healthy adults, younger than 28 years. During ageing, the typical shifts in the Lactobacillus sp. population may have been caused by some degenerative shifts in the gastrointestinal function such as reduction in transit time and digestive secretions ${ }^{(45)}$. Besides, the lowered reactivity of the 
immune system also emerges in the elderly ${ }^{(46-48)}$. It is possible that these changes could explain the characteristic pattern of the faecal lactobacilli associated with advancing age.

A striking difference concerned the L. rhamnosus species, which was found only in the faecal samples of adults $(21 \%)$, but not in the elderly. Walter ${ }^{(13)}$ has considered L. rhamnosus as one of the dominant Lactobacillus, though only $26 \%$ of healthy individuals and $6 \%$ of elderly harboured this species according to some other authors ${ }^{(4,41)}$. In our elderly group, the complete absence of L. rhamnosus is difficult to explain, considering the aggressive marketing of Gefilus, one of the L. rhamnosus GG products in Estonia. We hypothesise that in the infancy of the studied elderly people (with birth years from 1920 to 1940) when the resident Lactobacillus sp. biota of the gastrointestinal tract were formed, diet and environment did not favour the spread of this species.

Furthermore, during the next years of life, even the intensive spread of this probiotic strain did not help to colonise the seniors with previously well-formed microbiota.

The present results confirm that each person of both age groups had an individual set of combinations of different lactobacilli species, which is in agreement with previous, studies ${ }^{(26,41,49)}$. The individual specificity, on the one hand, and the temporal modulation of intestinal microbiota by diet, lifestyle and stress, on the other hand, complicate the understanding of the relationships between colonic microbiota signatures and host functions throughout the lifespan ${ }^{(17,50,51)}$.

The elderly are more prone to the metabolic syndrome, characterised by a higher blood glucose level and $\mathrm{BMI}^{(52,53)}$. In our previous study of the elderly, we could not find any significant link between lactobacilli counts and $\mathrm{BMI}^{(54)}$. In a larger number of individuals (adult and elderly persons), we detected a significant relationship between BMI and counts of cultivable lactobacilli, adjusted for age and sex. Why was it detected only when using bacteriological estimation of counts of lactobacilli? Discrepancies between RT-PCR and cultivable counts of lactobacilli have been found previously and were related to the multiplicity of $16 \mathrm{~S}$ ribosomal RNA gene copies, the presence of non-viable, or viable but not cultivable, bacterial cells and to free DNA ${ }^{(55,56)}$. Additionally, due to the complex taxonomy of lactobacilli, the primers designed for lactobacilli based on $16 \mathrm{~S}$ ribosomal RNA may also detect other related genera such as Pediococcus spp. and Weissella spp. ${ }^{(28)}$.

How could the increased number of lactobacilli, particularly those of the OHOL fermentation group, influence health parameters such as the blood glucose level and BMI? The intestinal lactobacilli support intestinal epithelial cell proliferation through the production of SCFA that provide energy for the host ${ }^{(57)}$. The main fermentation end product of the OHOL group is lactic acid. The lactobacilli of the FHEL and OHEL groups, including
L. paracasei and L. fermentum, produce not only lactic acid, but also acetic acid and succinate ${ }^{(12)}$. It can be speculated that intestinal colonisation by some species of the latter groups decreases the content of both glucose (hexoses) and fructose (pentoses) due to its most effective phosphoketolase pathway of carbohydrate fermentation ${ }^{(29)}$. Thus, the complex metabolic activities between the host and different groups of microbiota shape the nutrient environment of the gut ${ }^{(58)}$ and correspondingly the blood glucose level.

Lactobacilli also possess the ability to produce polyamines due to decarboxylation of amino acids ${ }^{(59,60)}$. The high amounts of polyamines could facilitate the absorption of glucose, increasing the number of glucose carriers in the membrane of enterocytes ${ }^{(61)}$. In Finnish elderly people, a positive correlation between the counts of administered L. acidophilus NCFM (OHOL fermentation type) and the values of polyamine spermine was detected ${ }^{(62)}$. This may be the reason for an increased BMI tightly bound to the glucose level of blood in persons colonised prevalently with several species of the OHOL group in the present study of both adults and the elderly.

The question arises whether the reduction of L. acidophilus and L. gasseri could influence the state of health of the elderly? Both L. acidophilus and L. gasseri harbour genes for formyl-CoA transferase and oxalyl-CoA decarboxylase that are obligate enzymes for oxalate degradation in the gastrointestinal tract. The genes for these enzymes are absent in L. johnsonii and L. plantarum ${ }^{(63)}$. It is possible that in the elderly, the higher prevalence of L. jobnsonii and L. plantarum species can increase oxalate concentration in urine. This could support the development of kidney stone disease, common in the elderly ${ }^{(64)}$.

According to the present study, L. sakei was found in a quarter of the investigated persons, yet it was unexpectedly associated with higher BMI. The ability of this species to metabolise complex carbohydrates into monosaccharides $^{(65)}$ may support their absorption by host cells. Some studies have indicated that L. sakei is one of the predominant food-associated Lactobacillus species that occurs in human faeces ${ }^{(5,28,66)}$. L. sakei has been isolated from meat, sausages and sauerkrauts, also used for the production of fermented meat products ${ }^{(67)}$. At the same time, it is one of the major spoilage organisms for vacuum-packed meat products ${ }^{(68)}$.

Tempting for future applications is our finding on the decreased blood glucose level in adults colonised with L. paracasei of the FHEL group. This finding is supported by data showing that administration of the close species of $L$. casei to diabetic mice reduced the glucose level of blood ${ }^{(69)}$. Likewise, a diet enriched with another Lactobacillus species of the FHEL group (e.g. L. rhamnosus GG) has resulted in an improved glucose tolerance test as well as in reduced blood glycated $\mathrm{Hb}$ values in experimental rats and pregnant women ${ }^{(70,71)}$ 
Altogether, this clearly hints at the different impact of particular Lactobacillus species of various fermentative groups on the metabolism of adults and the elderly having to be considered in the individual probiotic administration for health's sake.

\section{Conclusion}

There are substantial age-related (adults and the elderly) structural differences in the intestinal lactobacilli communities. The higher counts of intestinal lactic acid bacteria are associated with higher BMI and blood glucose content, while colonisation with different fermentative groups of lactobacilli is bound to the glucose levels both in adults and in the elderly. In developing blood glucose- and BMI-lowering species of lactobacilli as probiotics, their age- and metabolism-related differences should be taken into account.

\section{Acknowledgements}

We thank Irja Lutsar for critical reading of the manuscript and Pirje Hütt for help in statistical analysis. The authors' responsibilities were as follows: J. Š. was responsible for the study design, study performance, molecular analyses, data analyses and manuscript drafting; E. Sepp, E. Songisepp and K. L. were responsible for bacteriological analysis; H. K. was involved in clinical evaluation and the collection of samples; M. M. was the principal investigator and participated in the design of the study, coordination and drafting the manuscript. All authors contributed to the interpretation of data and in writing and approval of the final manuscript. None of the authors had a conflict of interest to declare. The present study was supported by grants from the Estonian Science Foundation (grant no. 6782) and the Ministry of Higher Education and Research (grant no. SF018255).

\section{References}

1. Hebuterne X (2003) Gut changes attributed to ageing: effects on intestinal microflora. Gastroenterology 6, 49-54.

2. Tiihonen K, Tynkkynen S, Ouwehand A, et al. (2008) The effect of ageing with and without non-steroidal antiinflamatory drugs on gastrointestinal microbiology and immunology. BrJ Nutr 100, 130-137.

3. Mitsuoka T (1992) Intestinal flora and ageing. Nutr Rev $\mathbf{5 0}$, 438-446.

4. Silvi S, Verdanelli MC, Orpianesi C, et al. (2003) EU Project Crownalife: functional foods, gut microflora and healthy aging. Isolation and identification of Lactobacillus and Bifidobacterium strains from fecal samples of elderly subjects for a possible probiotic use in functional foods. J Food Eng 56, 195-200.

5. Heilig HG, Zoetendal EG, Vaughan EE, et al. (2002) Molecular diversity of Lactobacillus ssp. and other lactic acid bacteria in the human intestine as determined by specific amplification of $16 \mathrm{~S}$ ribosomal DNA. Appl Environ Microbiol 68, 114-123.
6. Tannock GW (2004) A special fondness for lactobacilli. Appl Environ Microbiol 70, 3189-3194.

7. Vaughan EE, Heilig HG, Ben-Amor K, et al. (2005) Diversity, vitality and activities of intestinal lactic acid bacteria and bifidobacteria assessed by molecular approaches. FEMS Microbiol Rev 29, 477-490.

8. Garrity GM, Bell JA, Lilburn TG, et al. (2004) Taxonomic Outline of the Prokaryotes. Bergey's Manual of Systematic Bacteriology. Release 5.0, 2nd ed., pp. 401. New York: Springer-Verlag.

9. Sghir A, Gramet G, Saua A, et al. (2000) Quantification of bacterial groups within human faecal flora by oligonucleotide probe hybridization. Appl Environ Microbiol 66, $2263-2266$.

10. Hirano J, Yoshida T, Sugiyama T, et al. (2003) The effect of $L$. rhamnosus on enterohemorrhagic $E$. coli infection of human intestinal cells in vitro. Microbiol Immunol 47, 405-409.

11. Valeur N, Engel P, Carbajal N, et al. (2004) Colonization and immunomodulation by L. reuteri ATCC 55730 in the human gastrointestinal tract. Appl Environ Microbiol 70, 1176-1181.

12. Annuk H, Shchepetova J, Kullisaar T, et al. (2003) Characterization of intestinal lactobacilli as putative probiotic candidates. J Appl Microbiol 94, 403-412.

13. Walter J (2008) Ecological role of lactobacilli in the gastrointestinal tract: implications for fundamental and biomedical research. Appl Environ Microbiol 74, 4985-4996.

14. Cani PD \& Delzenne MN (2009) The role of the gut microbiota in energy metabolism and metabolic disease. Curr Pharm Des 15, 1546-1558.

15. Woodmansey EJ, McMurdo ME, Macfarlane GT, et al. (2004) Comparison of compositions and metabolic activities of fecal microbiota in young adults and in antibiotic-treated and nonantibiotic-treated elderly subjects. Appl Environ Microbiol 70, 6113-6122.

16. Vassos D, Maipa V, Voidarous C, et al. (2007) Development of human lactic acid gastrointestinal microbiotain a Greek rural population. Cent Eur J Biol 3, 55-60.

17. Nielsen DS, Møller PL, Rosenfeldt V, et al. (2003) Case study of the distribution of mucosa-associated Bifidobacterium species, Lactobacillus species, and other Lactic acid bacteria in the human colon. Appl Environ Microbiol 69, 7545-7548.

18. Song Y-L, Kato N, Lui C-X, et al. (2000) Rapid identification of 11 human intestinal Lactobacillus species by multiplex PCR assay using group- and species-specific primers derived from the 16S-23S rRNA intergenic spacer region and its flanking 23S rRNA. FEMS Microbiol Lett 187, 167-173.

19. Cagno R, Rizello CG, Garliardi F, et al. (2009) Imbalance of the faecal microbiota and volatile organic compounds between treated and untreated coeliac children. Appl Environ Microbiol 75, 3963-3971.

20. Kandler O \& Weiss N (1986) Regular non-sporing grampositive rods. In Bergey's Manual of Systematic Bacteriology, vol. 2, pp. 1209-1234 [PH Sneath, NS Mair and ME Sharpe, editors]. Baltimore, MD: Williams and Wilkins Baltimore.

21. Bäckhed F, Ding H, Wang T, et al. (2004) The gut microbiota as an environmental factor that regulates fat storage. Proc Natl Acad Sci U S A 101, 15718-15723.

22. Adlercreutz H (1990) Western diet and western diseases: some hormonal and biochemical mechanisms and associations. Scand J Clin Lab Invest Suppl 201, 3-23.

23. Costacou T, Bamia C, Ferrari P, et al. (2003) Tracing the Mediterranean diet through principal components and cluster analyses in the Greek population. Eur J Clin Nutr 57, 1378-1385.

24. Wenzel R (2007) Health care - associated infections. Major issues in early years of 21st century. Clin Infect Dis $\mathbf{4 5}$, $85-88$. 
25. Sepp E, Julge $\mathrm{K}$, et al. (2005) Intestinal microbiota and imunoglobulin E responses in 5-year-old Estonian children. Clin Exp Allergy 35, 1141-1146.

26. Mikelsaar M, Annuk H, Stsepetova J, et al. (2002) Intestinal Lactobacilli of Estonian and Swedish Children. Microb Ecol Health Dis 14, 75-80.

27. Bartosch S, Fite A, MacFarlane GT, et al. (2004) Characterization of bacterial communities in feces from healthy elderly volunteers and hospitalized elderly patients by using real-time PCR and effects of antibiotic treatment on the fecal microbiota. Appl Environ Microbiol 70, 3575-3581.

28. Walter J, Hertel C, Tannok GW, et al. (2001) Detection of Lactobacillus, Pediococcus, Leuconostoc, and Weisella species in human feces by using group-specific PCR primers and denaturing gradient gel electrophoresis. Appl Environ Microbiol 67, 2578-2585.

29. Axelsson L (1998) Lactic acid bacteria: classification and physiology. In Lactic Acid Bacteria, pp. 1-72 [S Salminen and A von Wright, editors]. New York: Marcel Dekker.

30. Tilsala-Timisjärvi A \& Alatossava $T$ (1997) Development of oligonucleotide primers from the 16-23S rRNA intergenic sequences for identifying different dairy and probiotic lactic acid bacteria by PCR. Int J Food Microbiol 35, 49-56.

31. Walter J, Tannock GW, Tilsala-Timisjarvi A, et al. (2000) Detection and identification of gastrointestinal Lactobacillus species by using denaturing gradient gel electrophoresis and species-specific PCR primers. Appl Environ Microbiol 66, 297-303.

32. Haarman M \& Knol J (2006) Quantitative real-time PCR analysis of fecal Lactobacillus species in infants receiving a prebiotic infant formula. Appl Environ Microbiol $\mathbf{7 2}$, 2359-2365.

33. Matsuda K, Tsuij H, Matsumoto K, et al. (2009) Establishment of an analytical system for the human fecal microbiota, based on reverse transcription-quantitative PCR targeting of multicopy rRNA molecules. Appl Environ Microbiol $\mathbf{7 5}$, $1961-1969$.

34. Mitsuoka T (1992) The lactic acid bacteria in health and disease. In The Human Gastrointestinal Tract, vol. 1, pp. 69-114 [BJB Wood, editor]. London: Elsevier Applied Science.

35. Marteau P, Pochart P, Dore J, et al. (2001) Comparative study of bacterial groups within the human cecal and fecal microbiota. Appl Environ Microbiol 67, 4939-4942.

36. Tannock GW (1991) The microecology of lactobacilli inhabiting the gastrointestinal tract. Adv Microbiol Ecol 11, 147-171.

37. Finegold SM, Sutter VL \& Mathisen GE (1983) Normal indigenous intestinal flora. In Human Intestinal Microflora in Health and Disease, pp. 3-31 [DJ Hentges, editor]. New York: Academic Press.

38. Finegold SM, Sutter VL, Sugihara PT, et al. (1977) Fecal microbial flora in seventh day adventist populations and control subjects. Am J Clin Nutr 30, 1781-1792.

39. Mikelsaar M (1993) Evaluation of the gastrointestinal microbial ecosystem in health and disease. PhD Thesis, University of Tartu.

40. Sepp E, Voor T \& Julge K (2006) Is intestinal microbiota bound up with changing lifestyle? In Modern Multidisciplinary Applied Microbiology, pp. 708-712 [Mendez-Vilas, editor]. Weinhein: Wiley-VCN Verlag.

41. Ahrne S, Nobaek S, Jeppsson B, et al. (1998) The normal Lactobacillus flora of healthy human rectal and oral mucosa. J Appl Microbiol 85, 88-94.

42. Reuter G (2001) The Lactobacillus and Bifidobacterium microflora of the human intestine: composition and succession. Curr Issues Intest Microbiol 2, 42-53.
43. Mikelsaar M \& Lencner A (1982) Mucosal lactoflora of gastrointestinal tract. In Mikrobielle Umwelt und/in antimikrobielle Massnabmen. Bd. 6. Mikroökologie des Magen-Darmkanals des Menschen (Microbial Environment and/or in Antimicrobial Action. vol. 6 Micro-ecology of the Gastrointestinal Tract of Man), pp. 89-96 [H Bernhard and M Knoke, editors]. Leipzig: Barth-Verlag.

44. Conway P (1989) Lactobacilli: fact and fiction. In The Regulatory and Protective Role of the Normal Microflora, pp. 263-283 [R Grubb, T Midtvedt and E Norin, editors]. Stockholm: Stockton Press.

45. Mariat D, Firmesse O, Levenez F, et al. (2009) The Firmicutes/Bacteroidetes ratio of the human microbiota changes with age. BMC Microbiol 9, 123.

46. Timiras PS (1996) Physiology of aging: standards for age-related functional competence. In Comprehensive Human Physiology, vol. 2, pp. 2391-2405 [R Greger and U Windhorst, editors]. Heidelberg: Springer-Verlag.

47. Gill HS, Darragh AJ, Cross M, et al. (2001) Optimizing immunity and gut function in the elderly. $J$ Nutr Health Aging 5, 60-91.

48. Tiihonen K, Ouwehand AC, Rautonen N, et al. (2010) Human intestinal microbiota and healthy ageing. Ageing Res Rev 9, 107-116.

49. Delgado S, Suárez A, Mayo B, et al. (2007) Identification of dominant cultivatable lactobacilli species from the faeces of Spanish healthy adults. Int Microbiol 10, 141-145.

50. Lay C, Rigottier-Gois L, Holmstrm K, et al. (2005) Colonic microbiota signatures across five northern European countries. Appl Environ Microbiol 71, 4153-4155.

51. Guarner F (2006) Enteric flora in health and disease. Digestion 73, 5-12.

52. Lichtenstein AH (1999) Optimal nutrition for the mature adult in health and disease. In Lifestyle Nutrition, pp. 106-126 [JT Dwyer and JM Rippe, editors]. Malden, MA: Blackwell Science.

53. Hashizume K, Suzuki S, Masahiro H, et al. (2006) Metabolic syndrome and age-related dementia: endocrinological aspects of adaptation to aging. Mech Ageing Dev 12, 507-510.

54. Mikelsaar M, Stsepetova J, Hütt P, et al. (2010) Intestinal Lactobacillus sp. is associated with some cellular and metabolic characteristics of blood in elderly people. Anaerobe 16, 240-246.

55. Farelly V, Rainly F, Stackebrandt E, et al. (1995) Effect of genome size and rrn gene copy number on PCR amplification of 16S rRNA genes from a mixture of bacterial species. Appl Environ Microbiol 61, 2798-2801.

56. Apajalahti J, Kettunen A, Nurminen PH, et al. (2003) Selective plating underestimates abundance and shows differential recovery of bifidobacterial species from human feces. Appl Environ Microbiol 69, 5731-5735.

57. Shanahan F (2002) The host-microbe interface within the gut. Best Pract Res Clin Gastroenterol 16, 915-931.

58. Falk PG, Hooper LV, Midvedt T, et al. (1998) Creating and maintaining the gastrointestinal ecosystem, what we know and need to know from gnotobiology. Microbiol Mol Biol Rev 62, 1157-1170.

59. Bover-Cid S \& Holzapfel WH (1999) Improved screening procedure for biogenic amine production by lactic acid bacteria. Int J Food Microbiol 53, 33-41.

60. Morene-Arribas MV, Polo MC, Jorganes F, et al. (2003) Screening of biogenic amine production by lactic acid bacteria isolated from grape must and wine. Int J Food Microbiol 84, $117-123$.

61. Johnson LR, Brockway PD, Madsen K, et al. (1995) Polyamines alter intestinal glucose transport. Am J Physiol 31, G416-G423. 
62. Ouwehand AC, Tiihonen K, Saarinen M, et al. (2009) Influence of a combination of Lactobacillus acidophilus NCFM and lactitol on healthy elderly: intestinal and immune parameters. Br J Nutr 101, 367-375.

63. Azcarate-Peril MA, Bruno-Barcena JM, Hassan HM, et al (2006) Transcriptional and functional analysis of oxalylcoenzyme A (COA) decarboxylase and formyl-CoA transferase genes from Lactobacillus acidophilus. Appl Environ Microbiol 72, 1891-1899.

64. Grases F, Costa-Bauza A, Prieto RM, et al. (2006) Renal lithiasis and nutrition. Nutr J 5, 23.

65. van Geel-Schutten GH, Flesh F, Ten Brick B, et al. (1998) Screening and characterization of Lactobacillus strains producing large amount of polysaccharides. Appl Microbiol Biotechnol 50, 697-703.

66. Dal Bello F, Hammes WP, Hertel C, et al. (2003) Increased complexity of the species composition of lactic acid bacteria in human feces revealed by alternative incubation condition. Microb Ecol 45, 455-463.

67. Hammes WP, Bantleon A, Min S, et al. (1990) Lactic acid bacteria in meat fermentation. FEMS Microbiol Rev 87, $165-174$.

68. Hammes WP \& Hertel C (1998) New development in meat starter cultures. Meat Sci 49, S125-S138.

69. Matzuzaki T, Nagata Y, Kado S, et al. (1997) Effect of oral administration of Lactobacillus casei on alloxan-induced diabetes in mice. APMIS 105, 637-642.

70. Yadav H, Jain S, Sinha PR, et al. (2007) Antidiabetic effect of probiotic Dahi containing Lactobacillus acidophilus and Lactobacillus case i in high-fructose fed rats. Nutrition 23, 62-68.

71. Laitinen K, Poussa T, Isolauri E, et al. (2009) Probiotics and dietary counselling contribute to glucose regulation during and after pregnancy: a randomised controlled trial. BrJ Nutr 101, 1679-1687. 